УДК $378-047.22: 005.6$

DOI:

Оксана Ісаєва, доктор педагогічних наук, професор кафедри педагогіки та інноваційної освіти

Національного університету “Львівська політехніка”, професор кафедри латинської та іноземних мов Львівського національного медичного університету імені Данила Галицького Ганна Шайнер, кандидат педагогічних наук, доцент кафедри іноземних мов

Національного університету “Львівська політехніка

Ірина Розман, кандидат педагогічних наук, доиент кафедри англійської філології та методики викладання іноземних мов Мукачівського державного університету

\title{
КЕЙС-ТЕХНОЛОГІЯ ЯК ІННОВАЦІЙНИЙ ПІДХІД ВИКЛАДАННЯ ДИСЦИПЛІН У КРИЗОВИХ УМОВАХ
}

У статті розглянуто роль кейс-технології у прочесі навчання майбутніх фахівців, аналізується ї̈ принцип, складові та особливості застосування. Кейс-технологія розглядається як інтерактивна система методів навчання, скерована на формування у майбутніх фахівців теоретичних знань, компетентностей, особистісних якостей та бажання вчитися упродовж життя. Інтегрований підхід до навчання розглядається важливою складовою сучасної освіти з точки зору дистанційного навчання, де кейс-технології необхідно використовувати для оновлення певного набору знань $і$ компетенцій, оскільки педагогічний потенціал кейсвикладання надзвичайно високий.

За допомогою кейс-технології студенти вчаться чітко і по-іншому аналізувати проблему; розрізняти основні та другорядні гіпотези, що характеризують певну ситуацію; визначити первинні або вторинні аспекти проблеми; науково пояснити реалізацію гіпотез ситуації; перевірити ефективність рішень.

Ключові слова: кейс навчання; кейс-технологія; заклади вищої освіти; підготовка студентів.

Puc. 1. Лim. 6.

Oksana Isayeva, Doctor of Sciences (Pedagogy), Professor of the Pedagogy and Innovative Education Department Lviv Polytechnic National University, Professor of the Latin and Foreign Languages Department

Lviv Danylo Halytsky National Medical University

Hanna Shayner, Ph.D. (Pedagogy), Associate Professor of the Foreign Languages Department, Institute of Humanities and Social Sciences,

Lviv Polytechnic National University

Iryna Rozman, Ph.D.(Pedagogy), Associate Professor of the English Philology and Methods of Teaching Foreign Languages Department Mukachevo State University

\section{CASE TECHNOLOGY AS AN UPDATED APPROACH TO TEACHING DISCIPLINES IN CRISIS}

The article highlights the role of the case-study technology in the process of teaching future professionals and provides the analysis of its principle, components and peculiarities of its application. An integrated approach to learning is considered as an important component of modern education in the view of distance learning, where case technologies should be used to update a certain set of knowledge and competencies as the pedagogical potential of case-study teaching is extremely high.

The relevance of the article is to update case technology as a rationalized methodology to teaching disciplines in the crisis of the pandemic covid-19.

The aim of the study is to distinguish the predictions for the use of case technology in the process of teaching students at higher educational establishments.

An innovative model of the students' learning behavior - from passive knowledge acquisition to active, creative, research-based, reflective education increasing cognitive interest - significantly affect the activation of thinking, stimulate intellectual activity and provide each student with the opportunity to form own route of self-education.

With the help of case technology, students learn to analyze the problem clearly and differently; distinguish between major and minor hypotheses that determine this situation; identify primary or secondary aspects of the problem; scientifically explain the implementation of hypotheses of this situation; test the effectiveness of solutions.

(C) О. Ісаєва, Г. Шайнер, 
Students gain practice working with limited information and ambiguous situations, thinking professionally, reflectively or disciplinary due to case-based learning. Case technology as a modern method of forming professional competence is widely used in the process of distance learning in order to update the professional competencies of future professionals.

Keywords: case-based learning; case technology; higher educational establishments; teaching students.

П остановка проблеми у загальному вигляді. Сучасні вимоги щодо підготовки фахівців у вишах вимагають оновленого підходу до методів і форм організації навчання, що передбачає зміну освітнього процесу в умовах пандемії ковід-19. Найпродуктивніші методи навчання мають передбачати формування професійних якостей та орієнтацію на особистість студента, його здібності, інтереси і мотиви. Власне інтегрований підхід до навчання розглядається важливою складовою сучасної освіти 3 огляду на дистанційне навчання, при якому варто застосовувати кейс-технології, які допомагають актуалізувати певний комплекс знань і компетенцій, що необхідно засвойти для розв'язання певної проблеми у поєднанні 3 навичками працевлаштування. Тобто інтегроване навчання передбачає комбінацію завдань у вигляді кейсу в поєднанні з практичною діяльністю.

Кейс-технологія як сучасний прийом формування професійної компетентності широко використовується у процесі дистанційного навчання 3 метою актуалізації фахових компетентностей майбутніх спеціалістів. Завдяки інтегрованим робочим навчальним програмам студенти можуть практикувати теорії та знання, які вони засвоїли під час навчання. Крім того, випускники можуть розвивати власний рівень впевненості та задекларувати новітні компетенції, а саме навички рефлексії, самовдосконалення, роботи в команді і комунікації. Тому університети повинні забезпечувати студентів реальним середовищем праці та практичним навчанням за допомогою навчальних програм, які включають кейс-технології. Виші повинні тісно співпрацювати 3 технічними галузями аби поліпшити працевлаштування випускників, оскільки ця проблема розглядається як один із ключових пріоритетів ефективності вищої освіти.

Актуальність розвідки полягає у тому, щоб актуалізувати кейс-технології як оновлений підхід до викладання дисциплін у кризових умовах пандемії ковід-19.

Мета дослідження - схарактеризувати перспективи застосування кейс-технології у процесі дистанційного навчання в умовах глобалізації освіти.

Відповідно до мети дослідження визначено такі завдання:
- визначити цілі, які передбачають кейстехнології;

- сформувати основні принципи застосування кейс-технології у процесі дистанційного навчання.

Аналіз останніх досліджень і публікацій. Заклади вищої професійної освіти здобули значний досвід щодо використання інтерактивних технологій навчання в умовах пандемії ковід-19, зокрема кейс-технології: В. Ліхачов, Я. Шиманська, О. Тарановська, Л. Добровольська, О. Макаров вивчали кейс-технології як продуктивний засіб формування компетентнісних професійних навичок; Ю. Сурмін - як засіб якісного оновлення української освіти; А. Долгоруков проаналізував метод case-study як сучасну технологію професійно-оріснтованого навчання; О. Шевченко розглядав навчальний потенціал кейс-методу; В. Ягоднікова розбирала кейс-метод як форму інтерактивного навчання майбутніх фахівців; О. Сидоренко, Ю. Сурмін, В. Чуба, П. Шеремета, Л. Штефан сформували теоретичні засади кейсметоду як інноваційного способу навчання і майбутньої професійної діяльності; Дж. Маан, Д. Крукшенк, Г. Сайкс, Т. Бердта також вивчали кейс-метод у процесі професійної підготовки педагогів.

Виклад основного матеріалу й обгрунтування отриманих результатів дослідження. Кейстехнологія розглядається як інтерактивна система методів навчання, скерована на формування у майбутніх фахівців теоретичних знань, компетентностей, особистісних якостей та бажання вчитися упродовж життя. На основі відбору, аналізу і синтезу інформації щодо врегулювання реальної чи змодельованої проблемної ситуації у контексті професійної діяльності, представленої у вигляді кейсу, допомагає майбутнім фахівцям розвиватися у певній галузі. Тобто кейс-метод розглядається як другорядний різновид аналізу, який формує власний особливий та неповторний зміст аналітичної діяльності і передбачає залучення різних видів аналітичної діяльності, необхідних для осмислення ситуації $[3,8]$.

Загальновідомо, що метод кейсів поєднує теорію $з$ практикою та сприяє розвитку навичок, включаючи комунікацію, активне слухання, критичне мислення, прийняття рішень та метакогнітивні навички, оскільки студенти застосовують знання про зміст курсу, 
розмірковують про те, що вони знають, та формують власний підхід до аналізу, аби зрозуміти сенс справи. Студентам можна прочитати кейс або дати завдання переглянути відео, відповісти на запитання та отримати першочерговий відгук, опублікувати запитання для обговорення чи поділитися ресурсами практичної діяльності.

Для того, щоб знівелювати невідповідність між спеціалізацією випускника та покладеними на нього завданнями, оскільки він не зможе практикувати або послуговуватися вмілим досвідом, який можна застосувати в різних контекстах та свої знання і навички на робочому місці, тому необхідно формувати кейси:

- за основою актуальності - кейси мають бути засновані на реальному фактичному матеріалі або змодельовані відповідно до реальної ситуації;

- за характеристикою розвитку особистості - кейси покликані розвивати креативність, критичне і аналітичне мислення, рефлексію, емоційний інтелект;

- за ступенем складності - кейси можуть поділятися на низької, середньої та високої складності.

Уважаємо, що метод кейсів також сприяє розвитку вмінь не лише аналізувати ситуації, але й оцінювати альтернативи, відбирати оптимальний варіант і складати план щодо його реалізації. Тобто, головне, що повинен містити в собі кейс:

- проблему, яка передбачає кілька варіантів ії вирішення;

- додаткову інформацію, яка уточнює деталі проблеми;

- чітко сформовані практичні завдання.

Якщо упродовж підготовки студентів у вишах систематично застосовувати такий підхід, то у студентів формуються аналітичні, практичні, творчих, комунікативні, соціальні навички за рахунок міжпредметної інтеграції. Таким чином, студенти вчаться реагувати на запитання і правильно їх ставити, вести бесіди, переконувати і вислуховувати опонентів, захищати власну точку зору, тобто студенти набувають стійких компетенцій щодо розв'язання практичних життєвих і професійних завдань. Підходи, що грунтуються на обговоренні, залучають студентів до роздумів та спілкування щодо майбутнього фаху. Тому викладачі можуть налаштувати кейс, в якому студенти будуть “задавати питання, узагальнювати зміст, генерувати гіпотези, пропонувати теорії або висовувати критичний аналіз. 3 цією метою викладачі повинні зосереджувати особливу увагу в процесі дистанційного навчання на:
- загальні стратегії навчання, мислення та вирішення проблем, тобто як студенти здобувають герменевтичний досвід (розуміння стратегіi);

- диференціацію у складності завдання, яка може вимагати різних когнітивних стратегій (прочедурне розуміння);

- усвідомлення того, як вчитися та виконувати завдання, у процесі якого здійснюється самоствердження студентів (детермінація розуміння з боку процедур, які беруть участь y формуванні діалогу між учасниками спілкування);

- саморегуляцію навчання, поведінки та мотивації (декларативне розуміння) на основі індивідуальних стилів навчання, можливостей та потреби розвитку, тобто активізація власних мислепроцесів через формування діалогової системи “запитання - відповідь".

Загальновідомо, що явища розглядаються всесторонньо за допомогою кейс-технологій на основі інформаційно-комунікативних технологій, що дає змогу оволодівати теоретичними знаннями і практичними навичками, формуючи особистість. Як стверджують науковці [6], на дослідження та прийняття рішень, пов'язаних 3 кар'єрою та навчанням, впливають мотивація, самоефективність і дисциплінованість інтересу. Саме соціальна когнітивна теорія кар'єри підкреслює механізми зворотного зв'язку разом iз внутрішньо- та міжособистісними чи часовими вимірами. Цей розвиток відбувається у рамках метакогнітивної системи, завдяки якій особистість розуміє когнітивні процеси та визначає, як формуються і розвиваються ідеї чи думки за допомогою методу кейсів.

Упродовж пандемії студенти повинні також розвивати метакогнітивні здібності, щоб приймати обгрунтовані рішення щодо навчання та кар'єри. Адже кейс-технологія одночасно відображає i практичну проблему, та й актуалізує певний комплекс знань, необхідний для іiі розв'язання, а також вдало поєднує навчальну, аналітичну і виховну діяльність упродовж академічної діяльності. Власне 3 цією метою доцільно використовувати педагогічні методи, які уможливлюють ефективне і чітке навчання, тобто допомагають студентам використовувати власний досвід і знання, аби вибрати відповідну інформацію, побудувати внутрішні та зовнішні зв’ язки чи підвищити свою продуктивність. Отож, дистанційне навчання уможливлює застосування кейс-технології 3 метою самостійного опрацювання і вдосконалення затребуваних практичних навичок, а саме: 
- аналітичних (вміння відрізняти дані від інформації, синтезувати, класифікувати, виділяти основну чи другорядну інформацію, аналізувати, представляти та здобувати інформацію, мислити чітко й логічно);

- практичних (формування навичок за допомогою використання теорії, методів та базових принципів);

- творчих (генерація альтернативних рішень);

- комунікативних (вміння вести дискусію, переконувати, використовувати медіа-засоби, кооперуватися у групи, захищати власну точку зору, переконувати опонентів, складати короткий та переконливий звіт);

- соиіальних (оцінка поведінки людей, вміння вислухати, підтримувати дискусію чи аргументувати протилежні думки, контролювати власні емоції тощо).

Зазначимо, що підходи до викладання кейсів мають грунтуватися на цілях навчання курсу та можуть бути адаптовані для малих, великих, гібридних і онлайн-класів. Отож, названа технологія навчання може використовуватися різними способами для надання, полегшення та оцінки методу кейсів.

Оскільки мета кейсу - навчання або перевірка визначених знань чи вмінь, в нього закладається комплекс практичних навичок, які учасникам потрібно здобути, а також встановлюється рівень складності та додаткові вимоги. Тобто, кожен кейс повинен мати чітко виражений характер і мету та передбачати: мотиваційно-орієнтований чи рефлексивно-оціночні етапи.

Варто зазначити, що кожен викладач повинен уніфікувати розроблені вимоги до кейсів відповідно до компетенцій особистісного характеру, тобто брати до уваги особливості дисципліни, яку вивчатимуть студенти за допомогою кейсів, дотримуватися організаційних правил роботи 3 кейсом у групі та онлайн. Погоджуємося з твердженням, що при укладанні кейсу необхідно дотримуватися певних вимог [4] a саме:

- за тематикою кейси повинні бути пов'язані 3 матеріалом, що вивчається;

- мати відповідний рівень складності;

- передбачати розгляд проблем, 3 якими зустрічаються фахівці в розрізі своєї кваліфікації;

- провокувати дискусію, вдосконалювати практичні навички;

- мати кілька рішень і спрямовувати на пошук відповідних шляхів розв'язання тієї проблеми.

Крім того, необхідно правильно визначити роль викладача, оскільки під час використання кейсметоду роль викладача суттєво відрізняється від традиційної. Робота викладача з аудиторією над кейсом охоплює кілька етапів [1]:

I eman - вступне слово викладача, формулювання основних питань кейсу;

II eman - об'єднання студентів у групи;

III eman - робота у складі груп;

IV eman - презентація рішень кожної групи;

$V$ eman - загальна дискусія, обговорення, запитання;

VI eman - виступ викладача, його аналіз групової роботи над кейсом, оцінювання якості роботи кожного учасника групи.

Уважаємо, що кейс-технології варто запроваджувати у вишах на основі силабусів 3 метою підготовки кваліфікованих фахівців сучасних ринкових спеціальностей, у яких домінує швидка зміна новітніх технологій. До кейстехнологій належать: метод ситуаціийного аналізу; метод іничденту; метод діагностики i синтезу інформації; метод креативного розв'язання ситуаційних завдань; ігрове проєктування; метод ситуаційно-рольових ігор; метод прийняття рішень; метод дискусї.

Оскільки кейси - це реальні або вигадані історії, які включають “освітнє повідомлення” або розповідають про події, проблеми, дилеми, теоретичні чи концептуальні питання, що потребують аналізу чи негайного прийняття рішень. Тому пропонується схема роботи студентів над кейс-ситуацією, що відображено на рисунку 1, оскільки цілі кейсу “більш широкі й більш амбітні” [5]:

Тобто, викладання на основі кейсів моделює реальні ситуації і пропонує студентам активно боротися зі складними проблемами, а саме формує інтелектуальне, рефлексивне і креативне розуміння певної проблеми [2]. За допомогою кейстехнології студенти вчаться чітко i диференційовано аналізувати проблему; вирізняти головні і другорядні гіпотези, що зумовлюють означену ситуацію; виділяти первинні чи вторинні аспекти проблеми; науково пояснювати реалізацію гіпотез цієї ситуації; перевіряти ефективність варіантів розв'язку.

Висновок. Викладачі відзначають навчальні переваги кейсів, включаючи більше залучення студентів до навчання, глибше розуміння ними концепцій, сталі навички критичного мислення та здатність встановлювати зв'язки між сенсом змісту і розглядати проблеми з різних точок зору. Робота в команді, підказки, вміння досліджувати ситуацію, розібратися у суті проблеми, запропонувати можливі рішення чи обрати найоптимальніше. 


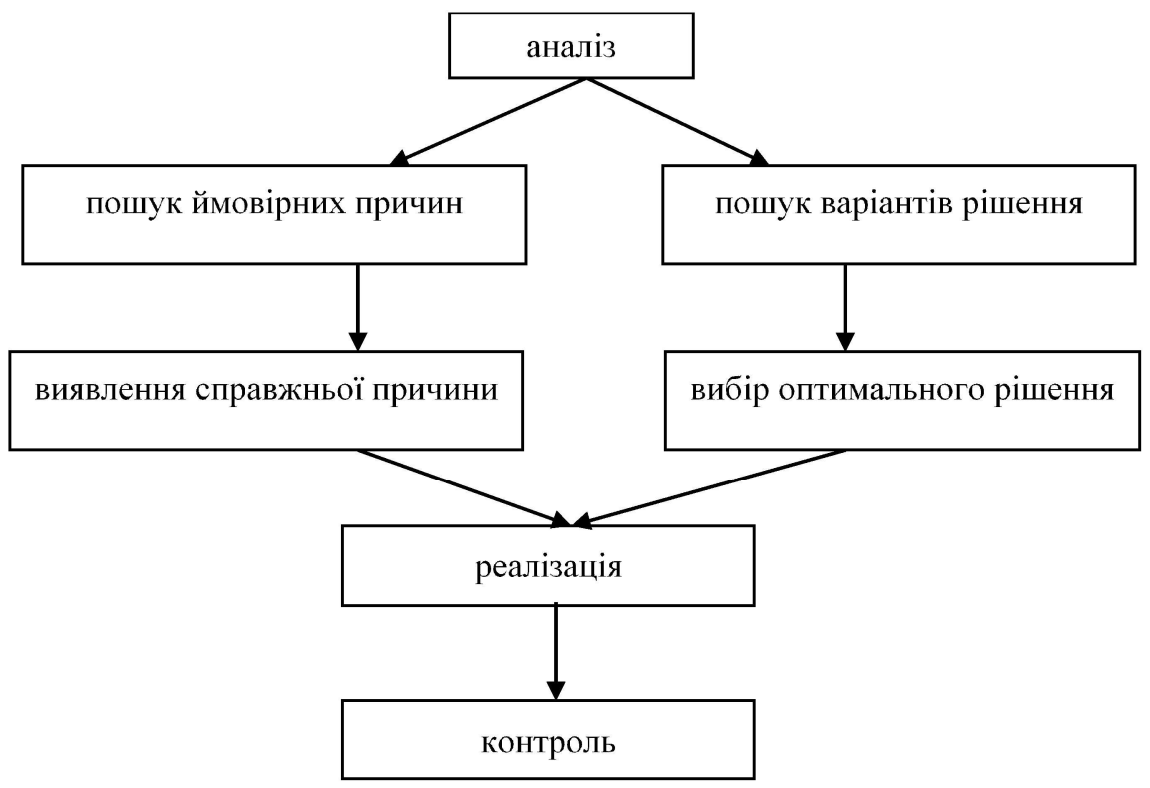

Рис. 1. Схема роботи студентів 3 кейсом

На основі практичного досвіду можна визначити, що кейстехнології поліпшують підготовку студентів, сприйняття ними досягнень у навчанні та відповідають цілям програми. Також завдяки навчанню на основі кейсів студенти здобувають практику працювати з обмеженою інформацією та неоднозначними ситуаціями, мислити професійно, рефлексивно чи дисциплінарно.

Перспективу подальших досліджень вбачаємо у вивченні STEM освіти у вишах.

\section{ЛІТЕРАТУРА}

1. Долгоруков А. Метод case-study как современная технология профессионально-ориентированного обучения. URL: http://www.vshu.ru/lections. php?tab id $=3 \& \mathrm{a}=$ info $\& \mathrm{id}=2600$

2. Зубар К. І. Інструктивні матеріали по впровадженню кейс-методу для методичного семінару. Методична доповідь. 2006. C. 10. URL: https:// pedkab.wordpress.com/.

3. Михайлова Е. А. Кейс и кейс-метод: процесс написания кейса. Маркетинг. № 5. 1999. С. 113-120.

4. Збірник міні-кейсів з дисципліни "Комунікативні процеси у навчанні”. / за ред. Л. Савенкової, В. Приходько. Київ, 2009. 343 с.

5. Стрекалова Н. Д., Беляков В. Г. Разработка и применение учебных кейсов: практическое руководство. Санкт-Петербургский филиал Нац. исслед. ун-та “Высшая школа экономики”. 2013. 80 с.

6. Lent, R. W., Brown, S. D., \& Hackett, G. Toward a unifying social cognitive theory of career and academic interest, choice, and performance. Journal of Vocational
Behavior. 45(1). (1994). P. 79-122. doi:10.1006/ jvbe.1994.1027.

\section{REFERENCES}

1. Dolgorukov, A. Metod case-study kak sovremennaya tekhnologiya professionalno-oriyentirovannogo obucheniya [Case-study method as a modern technology of vocational training]. Available at: http://www.vshu.ru/ lections.php?tab id $=3 \& a=i n f o \& i d=2600$ [in Russian].

2. Zuba, K. I. (2006). Instruktyvni materialy po vprovadzhennyu keys-metodu dlya metodychnoho seminaru [Instructional materials on the implementation of the case method for a methodical seminar]. Methodical report. p. 10. Available at: https://pedkab.wordpress.com. [in Ukrainian].

3. Mikhaylova, Ye. A. (1999). Keys i keys-metod: protsess napisaniya keysa [Case and case method: the process of writing a case]. Marketing. No.5.pp. 113-120. [in Russian].

4. Zbirnyk mini-keysiv z dystsypliny "Komunikatyvni protsesy u navchanni” (2009). [Collection of mini-cases in the discipline "Communicative processes in learning"]. (Eds.). L. Savenkova, V. Prikhodko. Kyiv, 343 p. [in Ukrainian].

5. Strekalova, N. D. \& Belyakov, V. G. (2013). Razrabotka i primeneniye uchebnykh keysov: prakticheskoye rukovodstvo [Development and use of case studies: a practical guide]. St. Petersburg branch of the National issled. University Higher School of the National issled. University "Higher School of Economic". 80 p. [in Russian].

6. Lent, R. W., Brown, S. D., \& Hackett, G. (1994). Toward a unifying social cognitive theory of career and academic interest, choice, and performance. Journal of Vocational Behavior. 45(1). pp. 79-122. doi:10.1006/ jvbe.1994.1027. [in English].

Стаття надійшла до редакції 22.11.2021 